\title{
人フ血清コレステロールに及ぼす食用油脂の影響（その 6) \\ Influence of Several Lipids on Human Serum Cholesterol (Part 6)
}

$$
\text { 試作マーガリンの影響 (1) }
$$

\section{Effect of Several Margarines on Trial (1)}

国立栄養研究所 (The National Institute of Nutrition)

鈴木慎次郎 (S. Suzuki) 梶原寿美子 (S. Kajiwara)

久我達郎 (T. Kuga) 手塚朋通 (T. Tezuka)

旭電化工業株式会社研究所

寺田喜巳男 (K. Terada)

Five kinds of trial margarines, Camellia oil and lard were taken, 60g, per day for a week by seven groups each group consisting of five girls, and serum cholesterol levels before and after the period were compared.

Five kinds of the margarines were made from

No. 2 Safflower oil (45\%) and hydrogenated Cottonseed oil (55\%)

No. 3 Safflower oil (45\%) and hydrogenated Cocconut oil (55\%)

No. 4 Corn oil (45\%) and hydrogenated Cocconut oil (55\%)

No. 5 Corn oil (45\%) and hydrogenated Cottonseed oil (55\%)

No. 6 Hydrogenated fish oil only

Results obtained were as follows :

All oils except lard, which distinctly increased the serum cholesterol level by $18 \%$, scarcely gave effect on the cholesterol level.

From the view point of composition of fatty acids of the used oils, there were no close corelations between their effects and the essential fatty acid contents, nor the saturated acid content $x$ essential acid content as reported in rats by Hegsted et al.

Only a mere corelation with their iodine value could be found.

〔はしがき】Hegsted 等は白ネ゙ミに種々の食用油脂を投与した結果, コレステロール低下作用は必須脂 酸 (リノール酸) 含量と飽和脂酸 (ヤシ油) 含量との積に比例すると報告している。これはまた逆にみると， 必須でない不飽和酸例えばオレイン酸が少いほどコレステリン低下作用は大きいことを示唆している。

この成績を追試することと，脂肪酸組成で鯨油と似ている魚油の作用を検討することが今回の目的である。

〔実験方法】試作マーガリン 5 種と椿油・ラード（成分は表示）計 7 種の油脂を毎日 $60 \mathrm{~g}$ ずつ35名（各群 5 名ずつ 7 組）の被検者に 7 日間とらせた。その間 4 回採血して血清コレステロールを分析した。

〔成績及び考察〕成績は図示の如く，ラードは着明に血清コレステロール増加作用を示すが，その他の試作 マーガリンはコレステロール水準に殆えど変化を与えなかつた。椿油も前後では殆えど変化を与えていないが 
食用油脂と血清コレステロール（各群 5 人, 1 日 $60 \mathrm{~g}$ )

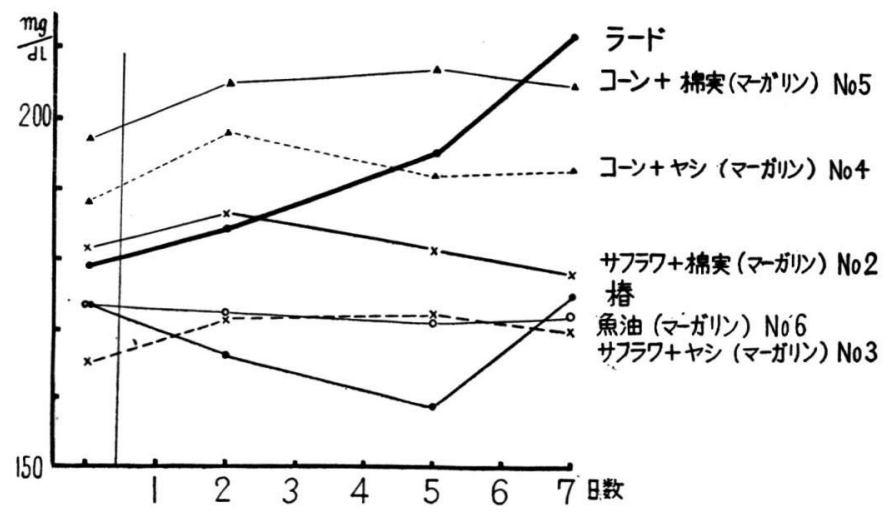

途中では最も低下させている。

これらのコレステロール変動作用を各 食用油脂の成分や性質と対照して考察し てみよう。

まず Hegsted のいう如く低下作用が 果して必須脂酸 $\times$ 飽和脂酸に比例するか ぞうかについて検討すると，第 1 表の最 下行に示す如く試作 $3 \cdot 4$ が最も低下さ せ，試作 6 ・椿油が増加させるはずであ るが,これら 4 者のコレステロール変動

作用に殆えど差異なく，むしろ前 2 者の方が増加させる傾向さえ伺われる。

また，オレイン酸或はイソオレイン酸の圧倒的に多い椿油或は試作 6 に増加作用は全く認められない。

以上の事実から，Hegsted の報告の如き傾向は少くとも人間においては全く認められないことが明かにな つた。

また, リノール酸含量では試作 $2 \cdot 3$ は $23 \sim 24 \%$ も含み, 試作 $4 \cdot 5$ の倍, 試作 6 の数 10 倍む含むにも拘 らず, コレステロール変動作用には明かな差違の認められなかつたことから, リノール酸含量だけがコレステ ロール低下作用の主因をなすものとは思われない。むしろ沃素価の高いこと或は飽和酸の少いことの方がコレ ステロール低下作用に平行しているようにみえた。

次の試作 6 即ち魚油マーガリンと椿油とはいずれもコレステロール值に全く変動を及ぼさなかつたが，この 2 種の油脂はオレイン酸を圧倒的に多く含むこと, リノール酸の少いこと, 従つて必須脂酸 $\times$ 飽和脂酸值の異 常に低いことなどの点において, 極めて相似の油脂である。しかもコレステロール值を全く増加させないとと は注目に価する。

第 1 表 試験油脂性状とコレステロール変動（脂肪酸はアルカリ異性化法）

\begin{tabular}{|c|c|c|c|c|c|c|c|}
\hline & $\begin{array}{c}\text { 試作 } 2 \\
\text { サ } フ \text { 油 } \\
(45) \\
\text { 棉実硬化油 } \\
(55)\end{array}$ & $\begin{array}{c}\text { 試作 } 3 \\
\text { サフ } \\
\text { (45) } \\
\text { ヤシ油 } \\
\text { (55) }\end{array}$ & 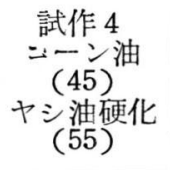 & $\begin{array}{c}\text { 試作 } 5 \\
\text { コ一油 } \\
\text { (45) } \\
\text { 棉実油硬化 } \\
\text { (55) }\end{array}$ & $\begin{array}{c}\text { 試作 } 6 \\
\text { 魚油硬化油 }\end{array}$ & 椿油 & ラード \\
\hline リノール 酸 & 24.2 & 22.9 & 11.2 & 10.9 & 0.4 & 2.7 & 4.4 \\
\hline リノレニン酸 & 0.23 & 0.28 & 0.23 & 0.33 & 0 & 0.05 & 0.44 \\
\hline アラキドン酸 & 0 & 0 & 0 & 0 & 0 & 0 & 0.16 \\
\hline $\begin{array}{l}\text { オンインン酸 } \\
\text { イソォレイン酸 }\end{array}$ & 60.3 & 30.0 & 39.8 & 72.7 & 87.0 & 86.0 & 55.4 \\
\hline 飽 和 酸 & 14.6 & 46.3 & 48.5 & 15.4 & 12.2 & 11.1 & 38.5 \\
\hline 沃 素 価 & 95.2 & 66.9 & 54.4 & 83.0 & 76.1 & 79.0 & 58.8 \\
\hline 鹼 化 価 & 194.2 & 223.7 & 223.8 & 194.4 & 183.8 & 186.5 & 196.7 \\
\hline 酸 価 & 0.04 & 0.05 & 0.07 & 0.07 & 0.05 & 0.06 & 0.05 \\
\hline 融 点 & 35.4 & 30.2 & 31.0 & 35.6 & 31.8 & - & 30.0 \\
\hline $\begin{array}{l}\text { リ } \text { 飧 和 酸 } \\
\times\end{array}$ & 353 & 1060 & 543 & 168 & 5 & 30 & 169 \\
\hline $\begin{array}{l}\text { コレステロール } \\
\text { の変動 }\end{array}$ & $-2 \%$ & $+3 \%$ & $+4 \%$ & $+3 \%$ & 0 & $+1 \%$ & $+18 \%$ \\
\hline
\end{tabular}


第 2 表 試験油脂の脂肪酸組成（ガスクロマトグラフ）

\begin{tabular}{|c|c|c|c|c|c|c|c|}
\hline 脂肪酸C 数 & $\begin{array}{c}\text { 試作 } 2 \\
\text { サ } \\
(45) \\
\text { (45) } \\
\text { 棉実硬化油 } \\
(55)\end{array}$ & $\begin{array}{l}\text { 試作 } 3 \\
\text { サ } \\
\text { (45) } \\
\text { ヤシ油 } \\
\text { (55) }\end{array}$ & $\begin{array}{l}\text { 試作 } 4 \\
\text { ב-油 } \\
\text { (45) } \\
\text { ヤシ硬化油 } \\
\quad(55)\end{array}$ & $\begin{array}{c}\text { 試作 } 5 \\
\text { コ一油 } \\
\text { (45) } \\
\text { 棉実硬化油 } \\
(55)\end{array}$ & $\begin{array}{c}\text { 試作 } 6 \\
\text { 魚油硬化油 }\end{array}$ & 椿油 & ラード \\
\hline C 8 & & 1 & & & & & \\
\hline 10 & & 3 & & & & & \\
\hline 12 & 1 & 20 & 2 & & & 2 & \\
\hline 14 & 2 & 11 & 1 & 12 & 11 & 3 & \\
\hline 16 & 20 & 11 & 25 & 22 & 27 & 29 & 8 \\
\hline $16-1$ & & & & & 6 & 3 & \\
\hline 18 & 5 & 7 & 5 & 9 & 6 & 12 & 87 \\
\hline $18-1$ & 31 & 10 & 42 & 27 & 4 & 48 & 3 \\
\hline-2 & 41 & 38 & 25 & 30 & 4 & 4 & 3 \\
\hline-3 & & & & & & & \\
\hline 20 & & & & & 22 & & \\
\hline 22 & & & & & 18 & & \\
\hline
\end{tabular}

〔結論】試作マーガリン 5 種と椿油・ラードについて，それらの血清コレステロール水準に及ぼす影響につ いて検討した。

その結果, ラードがコレステロール水準を $+18 \%$ と明かに増加させたが, 他の試作マーガリン 5 種と椿油 との効果は何れも +4 -2\% の範囲で大同小異であつた。

これらの結果を摂取油脂の脂肪酸組成と関係させて考えると, 新説として Hegsted 等がネズミについて得 た成績即ちコレステロール低下作用は必須脂酸含量と飽和脂酸含量との積に比例するという成績が想起される が,われわれの人体実験ではそのような関係は全く認められなかつた。

また、リノール酸含量にも比例せず, むしろ沃素価の高いこと或は飽和酸の少いことの方がコレステロール 低下作用に平行するように思われた。

文献

1) Hegsted, D. M., Gotis, A., Stare, F. G. :J. Nutr., 63, 377 (1957)

(受付：昭和 37 年 6 月 27 日)

抄 録

\section{アミノ酸インバランスに於ける白鼠の飼料摂取}

Effect of Amino Acid Imbalance on Food Intake and Preference. J. C.Sanhuja, A. E. Harper: Am.J. Physiol., 202,165 (1962) 動物実験で，飼料中のアミノ酸がアンバランスに なつた時，摂取量がいちぢるしく減少することが知 られている。フイブリン $6 \%$ を含えだ飼料にヒスチ ギン欠のアミノ酸混合物它添加してインバランスと し，あらかじめ無蛋白飼料で飼育した鼠にこれ岁投 与してみたが，ヒスチヂンを含有している対照と比
較して, 成長と摂取量が減少した。最初 3 日間は両 群に差はなかつた。また両群に無蛋白飼料を同時に 別の器で与えたところ，3 日後インバランス群はむ しろ無蛋白飼料の方を好えだ。インバランス飼料で は体重の増加を見たが無蛋白では減少した。長期の 実験では最初インバランス飼料を摂り, 体重は増加 するが，食欲が無くなり，無蛋白飼料を摄るように なるとそれと共に体重が下り，一定期間後再びイン バランス飼料を摂る。と云うことをくりかえした。 食欲の減少は味の影響ではないらしい。(小畠) 